\title{
HIGH TEMPERATURE FATIGUE BEHAVIOR OF 7075Al VIA LOW PLASTICITY BURNISHING
}

\author{
A. Abo El-Nasr *, M. Ayad * and M. Fattouh ** \\ * Lecturer and ** Professor and Chairman \\ Department of Production Engineering and Mechanical Design, \\ Faculty of Engineering, Menoufiya University, Shebin El-Kom, Egypt \\ E-mail: albadrawy@maktoob.com
}

\begin{abstract}
Rotating bending fatigue is considered to be an important characteristic of the mechanical parts. Herein, the high temperature fatigue behavior of 7075 aluminum is studied in terms of different mechanical and heat treatment procedures. These experiments were carried out in order to gain additional knowledge regarding the relationship between these processes and the fatigue behavior of the present alloy. A rotating bending test machine has been used to reach these goals. The fatigue experiments were performed under two different testing temperatures, 250 and 300 ${ }^{\circ} \mathrm{C}$, along with the room temperature experiments. Low plasticity burnishing technique was applied on part of the specimens as a mechanical means for enhancing the fatigue strength of the present alloy.
\end{abstract}

The results of the present work show that burnishing processes has played a considered role in increasing the fatigue strength of the present alloy. The enhanced fatigue resistance of the burnished specimens at high and room temperature was largely due to overall increase in the strength of the surface layer and delayed fatigue crack initiation on the surface.

Key Words: High temperature fatigue, $7075 \mathrm{Al}$, Low plasticity burnishing, Bending fatigue, Surface roughness. 


\section{IVIKUUUCIION}

High temperature fatigue in engineering materials is a problem faced in a large number of engineering and construction applications such as aerospace and aircraft structures. Extensive research work has been made to investigate the role of surface enhancement processes in increasing the fatigue resistance of the engineering materials. These processes were generally found to enhance the mechanical properties of the machined elements.

New surface enhancement technologies have been developed as mechanical means that can provide a layer of compressive residual stress of sufficient depth to effectively eliminate the bad influence of the aggressive environment. In general, all the currently available methods of surface enhancement develop a layer of compressive residual stress following mechanical deformation [1-6]. The methods differ primarily in how the surface is deformed and in the magnitude and form of the resulting residual stress and cold work distributions developed in the surface layers. For instance, laser shock peening (LSP) has been demonstrated to produce a pronounced increase in fatigue life of samples containing deep foreign object damage (FOD). Unfortunately, laser shocking is extremely expensive to perform, and slow and difficult to incorporate into aircraft manufacturing and overhaul shop environments, such as corrosion and high temperature oxidation [1-3]. Conventional air-blast shot peening (ASP) is routinely applied to a wide variety of aircraft components. High velocity impact of each particle of shot produces a dimple with a region of compression in the center. Typical compressive residual stress distribution reach a maximum approaching the alloy yield strength and extend to a depth of 0.05 to $0.5 \mathrm{~mm}[4,5]$. The magnitude of compression achieved depends primarily upon the mechanical properties of the alloy. The depth of the compressive layer and the degree of cold working depend upon the peening parameters including shot size, velocity, coverage and impingement angle. Because each shot impacts the surface at a random location, peening for sufficient time to achieve uniform surface coverage results in many multiple impacts producing a highly cold worked surface layer [6].

Low plasticity burnishing (LPB) is a surface enhancement process with significant economic and physical attributes that make it attractive for component repair/refurbishment applications in aging aircraft [3 ]. More recently, low plasticity burnishing (LPB) has been demonstrated to provide comparable depth and magnitude of compressive residual stress at far lower cost than for LSP. The LPB process can be performed easily on conventional turning or milling machine tools at costs and speeds comparable to conventional machining operations such as surface milling.

The present study aims mainly to investigate the effect of low plasticity burnishing technique on the high temperature fatigue of 7075 aluminum. The study also presents the fatigue results under two different temperatures along with room temperature results. Furthermore, fracture examinations were made in order to gain more knowledge regarding the fracture mechanism of material under investigation. 


\section{EXPERIMENTAL PROCEDURE}

\subsection{Material, Test Specimen and Mechanical Fatigue Testing}

The material used in this investigation was 7075 aluminum alloy (7075Al). The successful development of this outstanding member of the 7XXX series was made scissile by the beneficial effect of Chromium, which greatly improved the stresscorrosion cracking resistance of sheet made from this alloy. The chemical composition of the present alloy is given in Table 1. In this alloy, Zinc and Magnesium both have high solid solubility in aluminum and develop unusually highprecipitation-hardening characteristics. Copper additions of 1 to $2 \mathrm{wt} \%$ increase the strength properties of $\mathrm{Al}-\mathrm{Zn}-\mathrm{Mg}$ alloys to make the high-strength aircraft aluminum alloys $[7,8]$. In addition, this alloy can be easily worked and machined to a good surface finish which makes it applicable and widely used in the aircraft industry. It is also a heat treatable alloy and used in the T4 temper condition, which is a solution heat-treated and naturally aged to improve its mechanical strength [7].

Table 1 Chemical composition of the 7075Alminum alloy used in the present study.

\begin{tabular}{|c|c|c|c|c|c|c|}
\hline Element & $\mathrm{Zn}$ & $\mathrm{Mg}$ & $\mathrm{Cu}$ & $\mathrm{Fe}$ & $\mathrm{Cr}$ & $\mathrm{Al}$ \\
\hline Weight (\%) & 5.6 & 2.5 & 1.6 & 0.25 & 0.3 & Remainder \\
\hline
\end{tabular}

Cylindrical test specimens were machined from the as extruded bars. The geometry of fatigue specimen and extra details regarding the test specimen as well as the test. machine is found elsewhere $[9,10]$. Three sets of specimens with identical geometry were employed. The first set was tested in the as machined condition. The second and the third sets were subjected to solution treatment by heating upto $495^{\circ} \mathrm{C}$, for 1 and $3 \mathrm{hr}$., respectively, then water quenched and finally left at room temperature for at least 7 days prior fatigue tests. Burnishing processes has been applied on samples from each group.

The high temperature fatigue tests were conducted in open furnace using an Oho's Rotating Bending Fatigue Testing Machine (Model H7, Shimadzu Co., Kyoto, Japan). The specimens were subjected to bending fatigue stresses ranging from $\sim 75$ to $\sim 180 \mathrm{MPa}$ at 250 and $300{ }^{\circ} \mathrm{C}\left( \pm 2{ }^{\circ} \mathrm{C}\right)$. The bending fatigue stresses were calculated according to the applied bending moment and the diameter of gauge length of the specimen assuming that the specimen stays in elastic condition throughout its life [9]. The testing temperature was monitored using a thermocouple located at the center of the gauge length. Examinations of the fracture surfaces were done on the failed specimens by using scanning electron microscopy (SEM).

\subsection{Low Plasticity Burnishing Technique}

LPB technique is used as a mechanical means for producing a surface layer of compressive residual stress with significant magnitude and depth with minimal cold work. As a part of this study, the burnishing tool was designated and produced from tool steel and has been fitted on a general-purpose lathe. The process is shown in Fig. 1. The burnishing procedure is performed as following. The specimen is held first in 
tne turning machine whereas the burnishing tool is fixed, perpendicularly on the specimen, in the tool post (shown in Fig. 1. The front ball, inside the burnishing tool, is supported by spring with sufficient pressure to keep its depth constant with specified cold work. Dial gage is fixed at end of the spring to estimate the applied load. The ball is always in mechanical contact, with pre-determined force, with the surface to be burnished and is free to roll on the surface of the specimen. The front ball was made from high strength Nickel-Chromium alloy. A suitable mineral oil was used for the purpose of cooling and to improve the tribological behavior during the process.

Table 2. The working parameters used in the burnishing processes

\begin{tabular}{|c|c|c|c|c|}
\hline $\begin{array}{c}\text { Bumishing } \\
\text { Speed (m/min) }\end{array}$ & $\begin{array}{c}\text { Bumishing Feed } \\
(\mathrm{mm} / \mathrm{rev})\end{array}$ & $\begin{array}{c}\text { Burnishing Force } \\
(\mathrm{Kg})\end{array}$ & $\begin{array}{c}\text { Number of } \\
\text { Passes }\end{array}$ & $\begin{array}{c}\text { Front Ball } \\
\text { Diameter }(\mathrm{mm})\end{array}$ \\
\hline 28.5 & 0.1 & 12 & 4 & 12 \\
\hline
\end{tabular}
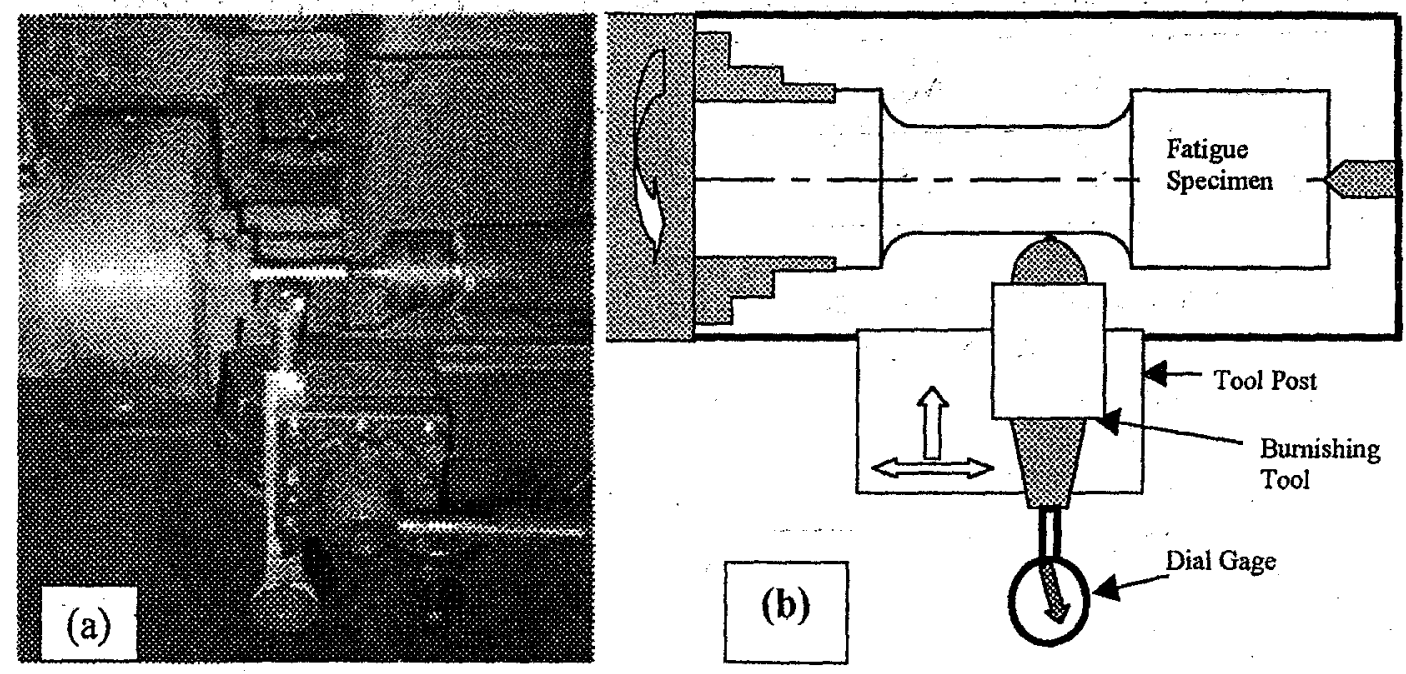

Fig. 1 The low plasticity burnishing technique used in the present study, (a) A photo of the process, and (b) Schematic illustration of the technique

It is well known in the LPB processes that each parameter has a significant effect on the resultant characteristics of the surface layer $[4,11]$. For example, preliminary tests that have been conducted in the present work have exhibited that serious effect on the surface layer occurs at feed rates above $0.4 \mathrm{~mm} / \mathrm{rev}$. In order to avoid surface deterioration, the optimal working parameters have been held constant throughout the burnishing processes. The optimum burnishing speed is found to be in the range from 20 to $28 \mathrm{~m} / \mathrm{min}$ for the $7 \mathrm{XXX}$ aluminum series. The burnishing feed should be less than $0.2 \mathrm{~mm} / \mathrm{rev}$. to cause considerable improvement in surface characteristics. Table 2 shows the working parameters used in the burnishing process for all the burnished specimens. Initial and final roughness of samples was estimated by using a Surftest-402 system. The average surface-roughness of the specimens, prior testing and burnishing, was found to be $\sim 2 \mu \mathrm{m}, \mathrm{Ra}$. 


\section{RESULTS AND DISCUSSION}

\subsection{Fatigue Behavior}

The stress vs number of cycles to failure (S-N) curves, on semi-logarithm scale, for the $7075 \mathrm{Al}$ are presented in Figs. 2 to 4 . The specimens, as shown in the figures, were tested under bending fatigue stresses at high temperatures, $T=250$ and $T=300$ ${ }^{\circ} \mathrm{C}$, and at room temperature as well. It is evident from the analysis of the figures that similar trends are observed in the three figures. It is obvious that as the fatigue stress increases the fatigue life decreases and vise versa. In addition, the specimens tested at $\mathrm{T}=30^{\circ} \mathrm{C}$ give longer fatigue lives than those tested at 250 and $300^{\circ} \mathrm{C}$.

As would not expected, heat treatment of the machined specimens reduced their fatigue strength. As revealed in Fig 2-4, heat exposure prior testing greatly reduced fatigue strength relative to the as-machined condition at all cyclic lives. Fatigue strength reduction relative to the as-machined condition of $25-35 \%$ and $40-50 \%$ was observed in the heat-treated specimens for 1 and 3 hrs respectively. It is found that the application of heat treatment has greatly reduced the residual stresses developed as a result of extrusion. It is clear from the results that no indication of fatigue limit was obtained under the present condition. This finding is in agreement with the result obtained by other researchers [12-14].

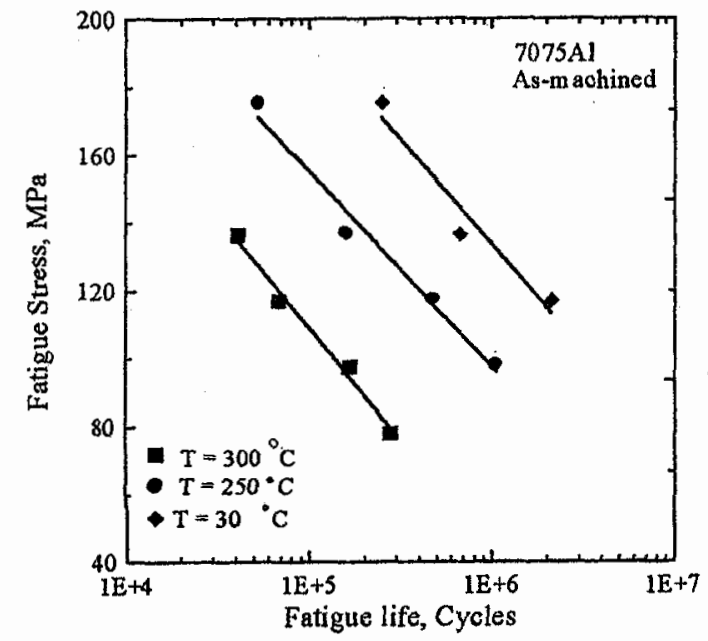

Fig 2 Fatigue stress against fatigue life for $7075 \mathrm{Al}$ in the case of as -machined.

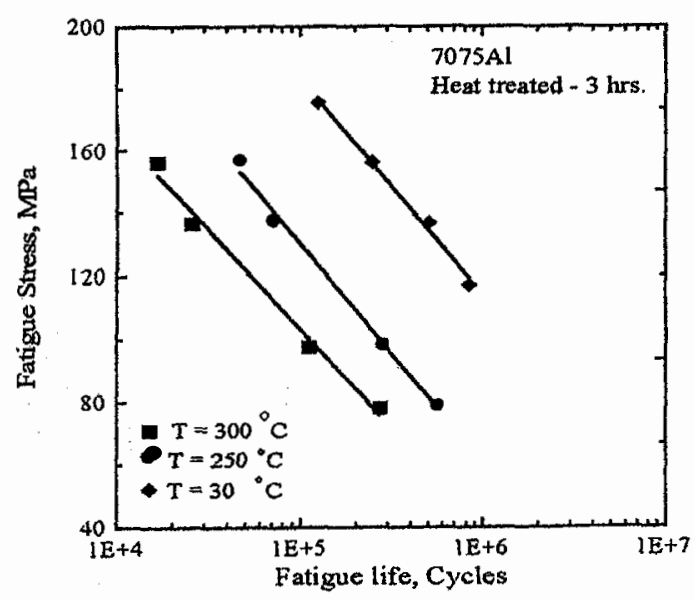

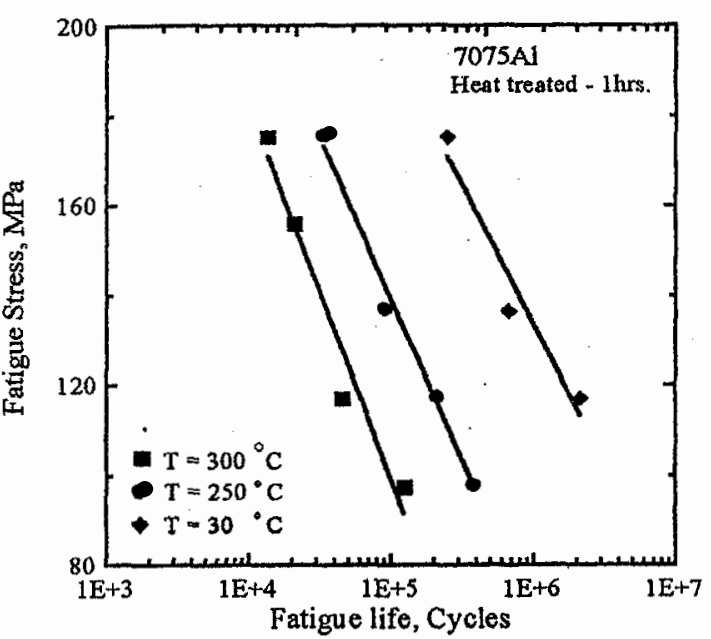

Fig 3 Fatigue stress against fatigue life for $7075 \mathrm{Al}$ in the case of heat treatment for $1 \mathrm{hr}$.
Fig 4 Fatigue stress against fatigue life for $7075 \mathrm{Al}$ in the case of heat treatment ( 3 hrs). 
The S-N curves for the burnished and unburnished specimens are presented in Figs. 5 and 6 , from which it can be seen that LPB process has improved the fatigue strength for all cases. For example, the fatigue life at $78 \mathrm{MPa}$ increased from $\sim 3 \times 10^{5}$ cycles, for unburnished specimens to $\sim 1.5 \times 10^{6}$ cycles for the burnished specimens with an increase of about half an order of magnitude. This increase in fatigue life is attributed to the compressive residual stresses at the surface layer caused by burnishing. These induced residual compressive stresses will reduce and hinder the propagation of the surface cracks eventually leading to fracture. The developed compressive stresses and frequently the strain hardening resulting from LPB will partially or completely compensate for the existing tensile stress within the specimen. This enhancement in fatigue life may also delay the crack growth by the residual compressive stresses induced in surface and subsurface layers.

The effect of burnishing processes on the surface roughness of the original machined specimens and heat treated specimens for 1 and 3 hrs are shown in Table 3 . The table shows the results of three repeat measurements made of two samples representing the conditions shown. The original surface roughness has been improved to be $1.2 \mu \mathrm{m}$, $\mathrm{Ra}$. Heat exposure caused a very rough and non-uniform surface finish as indicated. Fig. 7 shows typical surface roughness of heat-treated specimen prior and after burnishing. As seen significant improvement in the roughness is obtained. The considerable improvement in surface roughness increased the structural homogeneity of the surface layer and also increased the residual compressive stresses. This increase in the strength of the surface layer increases consequently the fatigue resistance of the material under investigation.

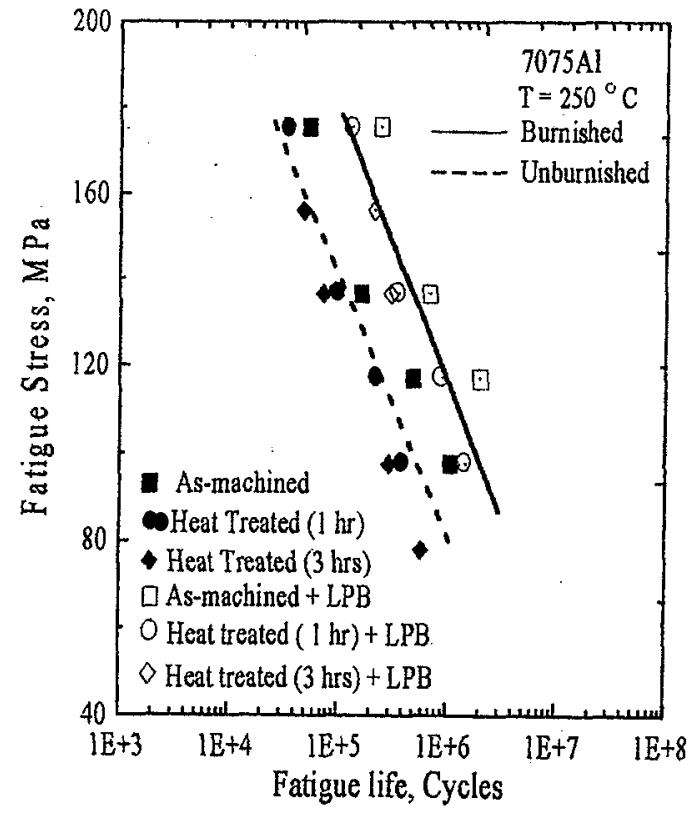

Fig 5 Comparison between fatigue lives for burnished and unburnished 7075Al specimens tested at $\mathrm{T}=250^{\circ} \mathrm{C}$

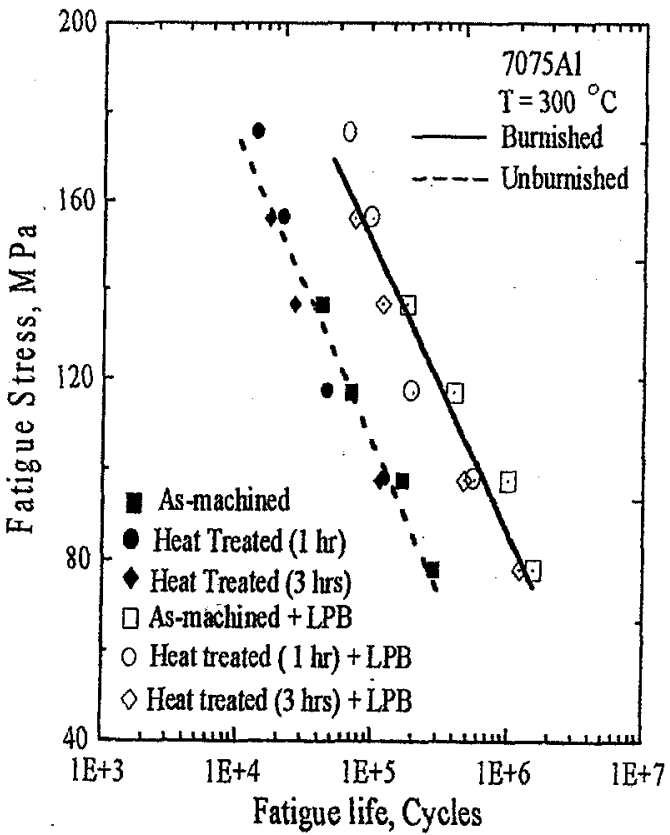

Fig 6 Comparison between fatigue lives of burnished and unburnished $7075 \mathrm{Al}$ specimens tested at $\mathrm{T}=300^{\circ} \mathrm{C}$ 
As seen from these results that burnishing treatment increased the fatigue life approximately up to half an order of magnitude relative to the as machined condition at all cyclic live. This enhancement in fatigue life is attributed to delay in crack growth by the residual compressive stresses induced in surface and subsurface layers as a result of the application of burnishing process.

Table 3. Surface roughness of $7075 \mathrm{Al}$ specimens before and after burnishing

\begin{tabular}{|c|c|c|}
\hline \multirow{2}{*}{$\begin{array}{c}\text { Temperature } \\
\text { Exposure (hr.) }\end{array}$} & \multicolumn{2}{|c|}{ Roughness, $(\mu \mathrm{m}, \mathrm{Ra})$} \\
\cline { 2 - 3 } & As-machined & Burnished \\
\hline 0 & $2 \pm 1$ & $1.2 \pm 1$ \\
\hline 1 & $13 \pm 5$ & $6 \pm 3$ \\
\hline 3 & $17 \pm 7$ & $8 \pm 4$ \\
\hline
\end{tabular}

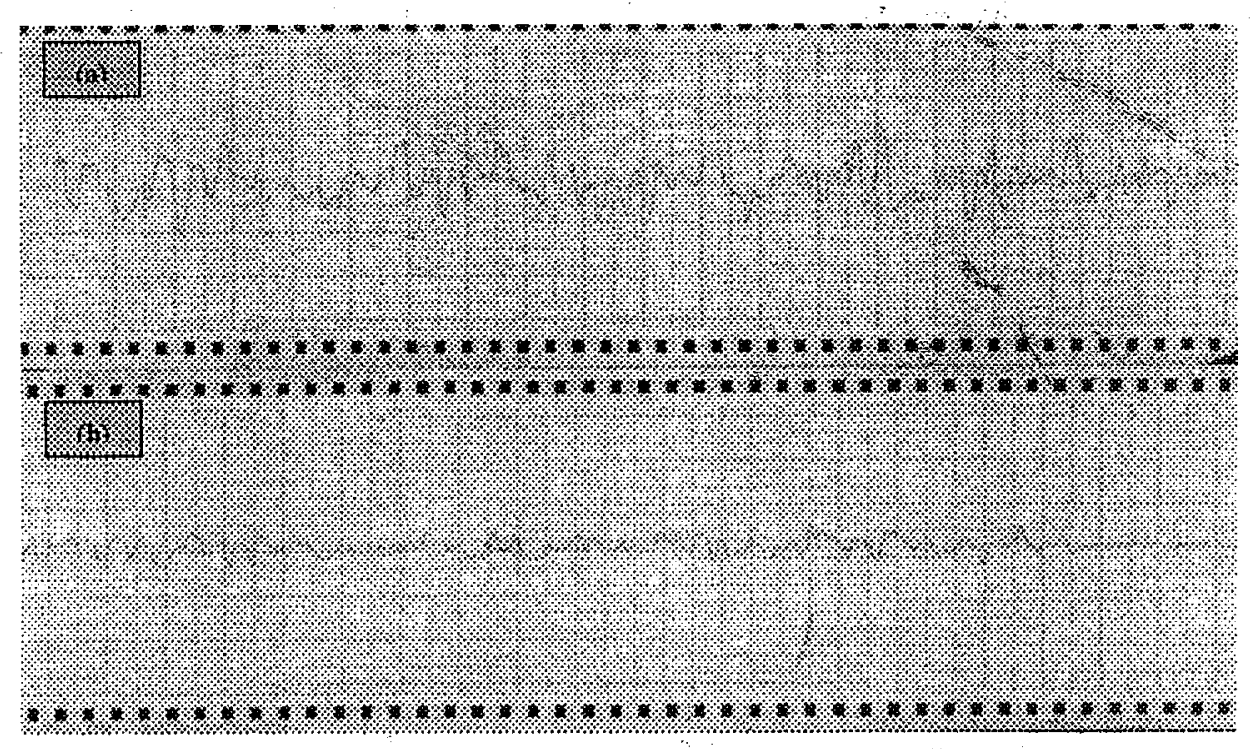

Fig. 7 Surface roughness of specimen has been heat treated for 3 hrs, (a) unburnished and (b) burnished surfaces.

\subsection{Fracture Characteristics}

The fracture surface characteristics are presented in Fig. 8 and 9 . The fracture surface, as shown, is associated with the formation of striations. The size and density of striations indicate the amount of plasticity that undergoing through the crack growth. Evidence of the presence of a role of the LPB is observed. It is interesting also to note that the duetile transgranular fracture modes were observed on the fracture surface.

As mentioned, fatigue tests in the present study were conducted under rotating bending stresses, thus the specimens are subjected to different stress gradients. It is well known that two different types of the internal stresses are generally existed in this type of fatigue specimens namely; tension and compression. These internal stresses change simultaneously from tension to compression and vise versa throughout the duration of the fatigue test. This action of transition from one to the 
other causes an opening and closing of the formed crack mouth [9]. The upper part experiences tension whereas the lower part experiences compression. The maximum internal stresses are developed at the specimen surface. The crack will then initiate at the region where the maximum stresses will develop. So the presence of pits and/or inclusions resulted from the high temperature exposure, at such areas will generate a large amount of stress concentration and consequently will crack the surface.

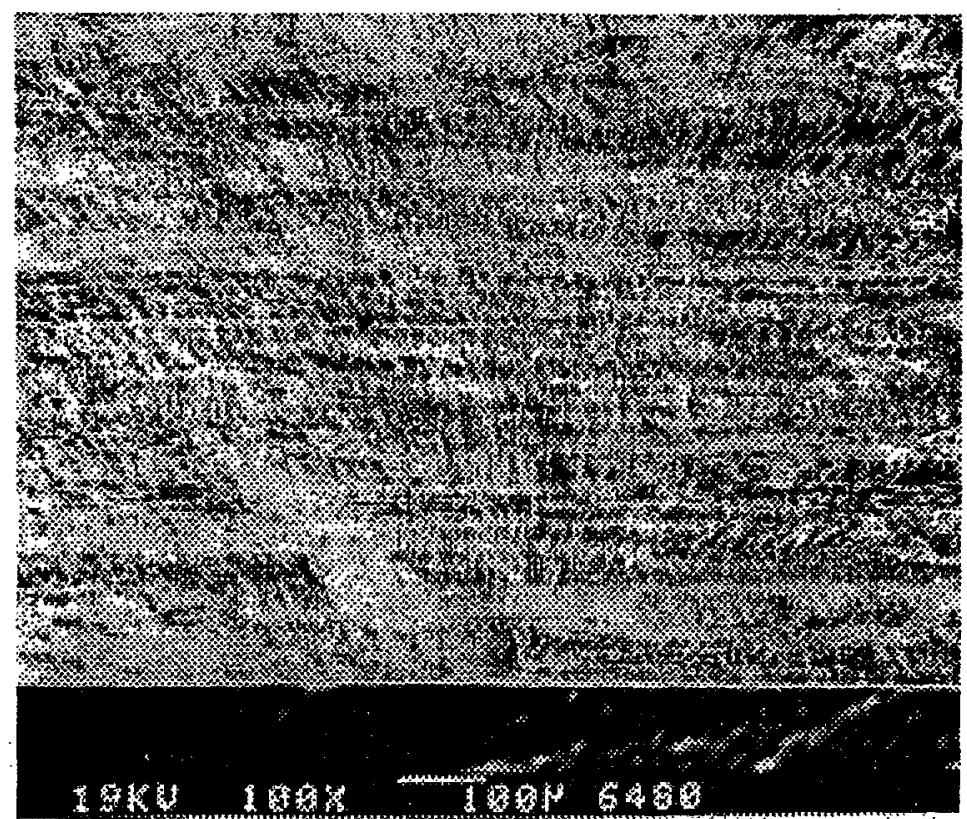

Fig. 8 SEM of a typical fatigue fracture of a burnished specimen tested at $250^{\circ} \mathrm{C}$. Striations are observed on the fracture surface, $X 100$.

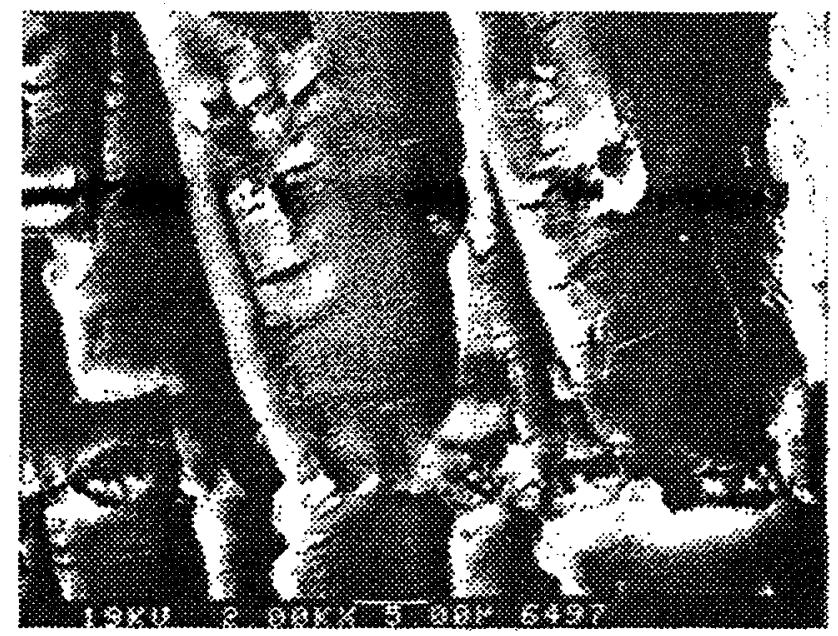

Fig. 9 SEM of the fracture surfaces with high magnification, striated fatigue feature, $\mathrm{X} 2000$.

It is well established that the surface of a component is prone to bending fatigue. Fatigue failures usually start at the specimen surface because of direct interaction with the aggressive environment in addition to the development of maximum tension and compression stresses $[15,16]$. On the other hand, High temperature oxidation 
attack often produces pitting of the imposed surface of the tested material. These pits act as a source of undesired defects and frequently produce a reduction in fatigue strength of the material. When oxidation and fatigue occurs simultaneously, the attack greatly accelerates the rate at which fatigue cracks propagate. However, when oxidation attack occurs simultaneously with fatigue loading, a very pronounced reduction in fatigue strength results in [17]. Hence, a means that can strengthen the surface will normally increase the fatigue resistance. Since, the environment will change the mechanical and structure state of the surface layer, it is natural to expect that the fatigue properties of the present material are also affected. It is believed that the using of the LPB during the high temperature testing as surface enhancement will reduce the effect of the oxidation attack, particularly room temperature. LPB has been shown to arrest the existing cracks up to $0.5 \mathrm{~mm}$ deep and to improve foreign object damage (FOD) providing full tolerance to $0.25 \mathrm{~mm}$ deep FOD in the present alloy. The surface finish produced by LPB is invariably superior to the original offering the further benefit of improved eddy current inspection capability on LPB processed components.

\section{CONCLUSIONS}

1- High temperature fatigue behavior of $7075 \mathrm{Al}$ specimens was examined under different testing conditions. The results show that burnishing processes has played a considered role in increasing the fatigue life, up to half an order of magnitude, of the present alloy: The significant improvement in surface roughness, as a result of burnishing, increases the structural homogeneity of the surface layer and also increases the residual compressive stresses. The enhanced fatigue resistance of the burnished specimens at high temperature was largely due to overall increase in the strength of the surface layer and delayed fatigue crack initiation on the surface.

2- The fatigue lives of the lower temperature $250{ }^{\circ} \mathrm{C}$ exhibit the longer lives over than those tested under higher temperature $300^{\circ} \mathrm{C}$ for all the three previous cases. The as-machined specimens show longer fatigue lives compared with the heat-treated specimens. It is expected that the heat treatment has give more degradation of the high temperature fatigue resistance of the alloy

3. Typical fatigue fractures was observed for the burnished specimens. Intense striations are found indicating the amount of plasticity that undergoing through the crack growth. It is believed that the using of the LPB prior high temperature testing as surface enhancement will reduce the effect of the oxidation attack.

\section{REFERENCES}

1. W. Zinn and B. Scholtes, "Mechanical Surface Treatments of Light Weight Materials - Effects on Fatigue Strength and Near-Surface Microstructures", J. of Mater. Eng. \& Performance, V. 8 (2), April (1999) pp. 145-151.

2. I. Altenberger, "Cyclic Deformation and Near Surface Microstructures of Shot Peened or Deep Rolled Austentic Stainless Steel AISI 304", Mater. Sci. \& Eng. A264 (1999) pp. 1-6.

3. A.H. Clauer, "Laser Shock Peening for Fatigue Resistance", Surface Performance of Titanium, J.K. Gregory et al. Eds., TMS, Warrendale, PA, (1996) pp. 217-230. 
4. Prevey, P.S., and Cammett, J. "Low Cost Corrosion Damage Mitigation and Improved fatigue Performance of Low Plasticity Burnished 7075-T6", Proc. $4^{\text {th }}$ Int. Aircraft Corrosion Workshop" Solomons, MD, Aug. 22-25, (2000), pp. 213283.

5. Zaid, A.I.O., Ababneh, M.A., and Al-Haddid, T.N., "Effect of Shot Peening on The Fatigue Strength of 2024-T3 Aluminum Alloy in The Unwelded and Welded Conditions", Current Advances in Mech. Design and Prod., $7^{\text {th }}$ Cairo University Inter. Conf., (7 ${ }^{\text {th }}$ MDP) Cairo, Feb. 15-17, (2000) pp. 339-346.

6. D. Lombardo and P. Baily, "The Reality of Shot Peen Coverage", The $6^{\text {th }}$ Inter. Conf. On Shot Peening, J. Champaign ed., CA, (1996) pp. 493-504.

7. Smith, W.F., "Structure and Properties of Engineering Alloys", McGraw-Hill Inc., (1993) pp. 312-323.

8. Yousefiani, A., El-Nasr, A.A., Mohamed, F.A., and Earthman, J.C.; "High Temperature Deformation and Rupture of $7075 \mathrm{Al}$ under Multiaxial Stress States", Proc. of the 7th Int. Conf. on Creep and Fracture of Engineering Materials and Structures, edited by J.C. Earthman and F.A. Mohamed, Aug. 1015, (1997), pp. 439-448, University of California, Irvine, USA.

9. Ayad, M. and Abo El-Nasr, A. "High Temperature Fatigue of 304 Stainless Steel under Different Gas Environments", $7^{\text {th }}$ Inter. Conf. on Prod. Eng., Develop., and Control, Alexandria University, Egypt, Feb. 13-15, (2001), 1513-1522.

10. Abo El-Nasr, A. and Ayad, M. "Effect of Multi-Step Loading on High Temperature Fatigue of 304 Stainless Steel", 6 $6^{\text {th }}$ Inter. Conf. on Prod. Eng. and Design for Development, Ain-Shams University, Cairo, Egypt, Feb. 12-14, (2002).

11. El-Axir, M.H., "A Study of Some Effects of Burnishing on The Premachined Surface Characteristics", M.Sc. Thesis, Library of Faculty of Engineering, Menoufiya University, Egypt, (1986), pp. 16-25.

12. Suresh, S., "Fatigue of Materials", Cambridge Solid State Science Series, Cambridge University Press, (1991).

13. Kettunen, P.O., "Statistical Theory as Applied to Cyclic Hardening", Acta Mater., 48 (2000), pp. 2231-2238.

14. Chen, D., Gilbert, C.J., Zhang, X.F. and Ritchie, R.O., "High Temperature Cyclic Fatigue Crack Growth Behavior in an in Situ Toughened Silicon Carbide", Acta. Mater., 48 (3) (2000), pp. 659-674.

15. Cruz, P. And Ericsson, T., "Influence of Sea Water on the Fatigue Strength and Notch Sensitivity of A Plasma Nitrided B-Mn Steel"; Mater. Sci. Eng., A247, (1998), pp. 204-213

16. Bensussan, P., Piques, R., and Pineau, A., "A Critical Assessment of Global Mechanical Approaches to Creep Crack Initiation and Creep Crack Growth in 316L Steel", in Nonlinear Fracture Mechanics, V.1, Time dependent Fracture, ASTM STP995, (1989), pp. 27-54.

17. Maile, K., Klenk, A., Granacher, J., Schellenberg, G. and Tramer, M., "Creep and Creep Fatigue Crack Behavior of $1 \mathrm{Cr}$-and $9 \mathrm{Cr}$-Steels", Key Engineering Materials, Proc. of the $8^{\text {th }}$ Inter. Conf. On Creep and Fracture of Engineering Materials and Structures, Nov. 1-5, (1999) v.171, Tsukuba, Japan. 


\title{
سلوك الكلال عند درجات المرارة المرتفعة لسبيكة ه V. V ألومنيوم المصقولة
}

\author{
د.البدراوى على أبو النصر ، د. محمد عبد العزيز غياد ، أ.د. محمد فتوح عبد الحميد \\ قسم هندسة الإنتاج و التصميم الميكانيكى ، كلية المهندسة \\ جامعة المنوفية ، شبين الكوم ، مصر
}

الملخص :

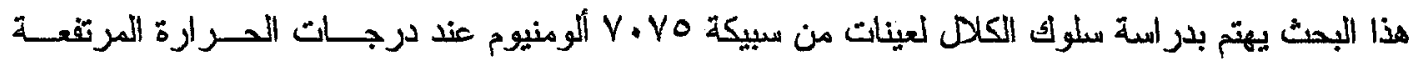

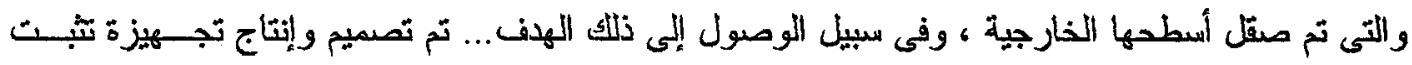

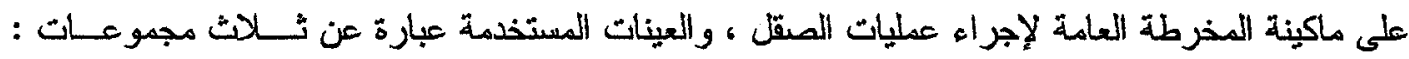

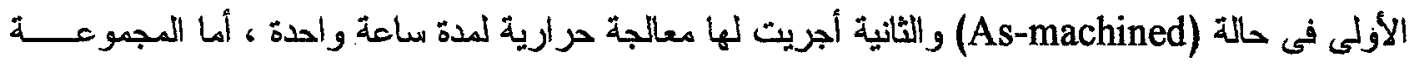

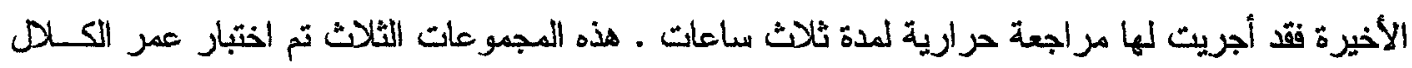

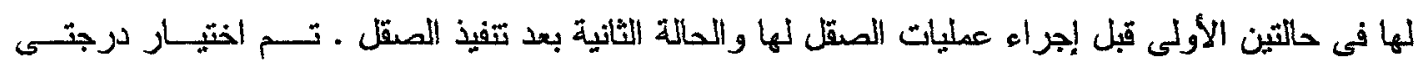

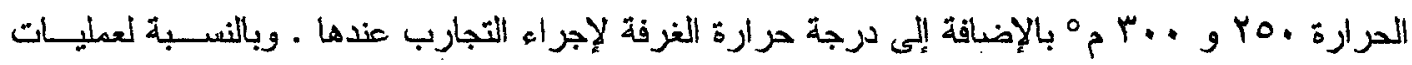

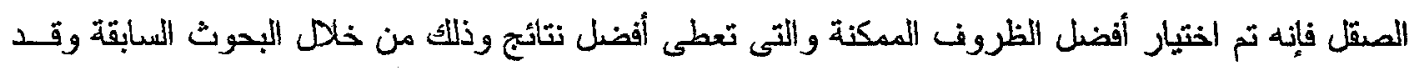

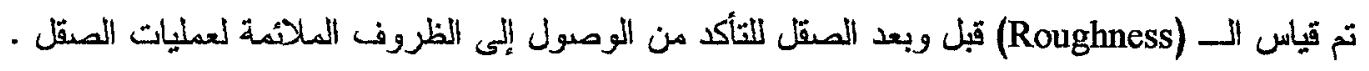

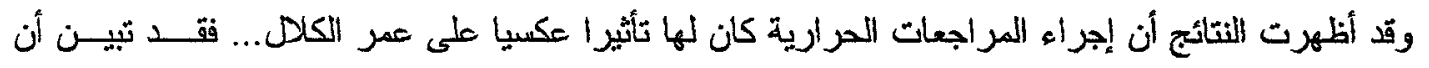

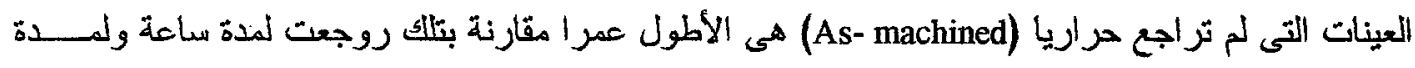

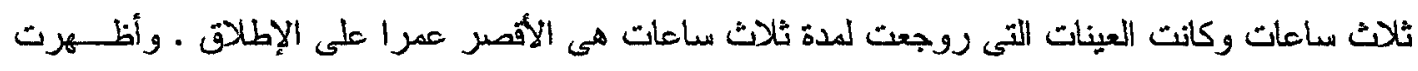

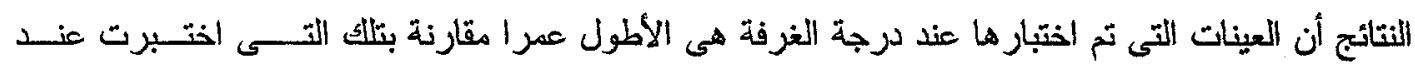

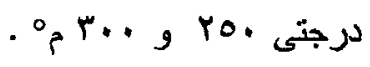

أما بالنسبة للعينات التى تم تنفيذ الصقل لأسطحها الخارجية فإن عمر الكلال الخاص بها قــــ ازداد بصــورة

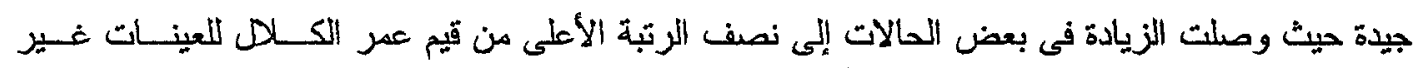

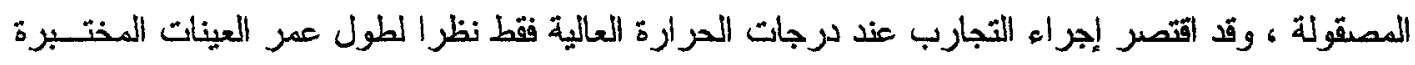

عند درجة حرارة الغرفة .

وقد أظهرت الفحوص المجهرية الخاصة بسطح الكسر باستخدلم الماسح الإلكترونى (SEM) أن خصـسائص كسر الكلل كانت مصاحبة للعينات التى تم صقلها حيث ظهرث التموجات السطحية بكثافة مبتدئة من الطبقــة

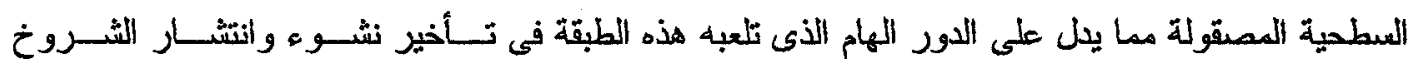

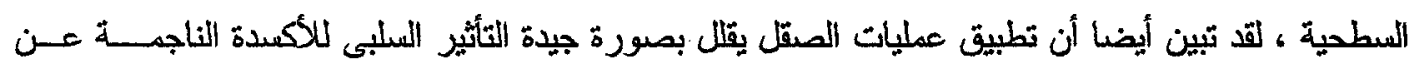
الاختبار عند درجات حرارة مرتفعة. 